\title{
Correction to: Impact of tourniquet during knee arthroplasty: a bayesian network meta-analysis of peri-operative outcomes
}

\author{
Filippo Migliorini ${ }^{1}$ (1) $\cdot$ Nicola Maffulli ${ }^{2,3,4} \cdot$ Paolo Aretini $^{5} \cdot$ Andromahi Trivellas $^{6} \cdot$ Markus Tingart $^{1} \cdot$ Jörg Eschweiler $^{1}$. \\ Alice Baroncini ${ }^{1}$
}

Published online: 13 March 2021

(c) The Author(s) 2021

\section{Correction to: Archives of Orthopaedic and Trauma Surgery https://doi.org/10.1007/s00402-020-03725-8}

The original version of this article unfortunately contained a mistake. In Fig. 2, one particular aspect of the quality of the article by (Alexandersson et al.) has been wrongly evaluated (Blinding of outcome assessment), and should be instead ' + ' instead of '?'.

The corrected Fig. 2 is given in the following page.

The original article can be found online at https://doi.org/10.1007/ s00402-020-03725-8.

Filippo Migliorini

migliorini.md@gmail.com

1 Department of Orthopaedic Surgery, RWTH Aachen University Clinic, Pauwelsstraße 30, 52074 Aachen, Germany

2 Department of Medicine, Surgery and Dentistry, University of Salerno, Via S. Allende, 84081 Baronissi, SA, Italy

3 School of Pharmacy and Bioengineering, Keele University School of Medicine, Thornburrow Drive, Stoke on Trent, England

4 Barts and the London School of Medicine and Dentistry, Centre for Sports and Exercise Medicine, Queen Mary University of London, Mile End Hospital, 275 Bancroft Road, London E1 4DG, England

5 Fondazione Pisana per la Scienza, Via Ferruccio Giovannini, 13, 56017 San Giuliano Terme, Pisa, Italy

6 Department of Orthopaedics, David Geffen School of Medicine at UCLA, 10833 Le Conte Ave, Los Angeles, CA 90095, USA 
Fig. 2 Cochrane risk of bias summary

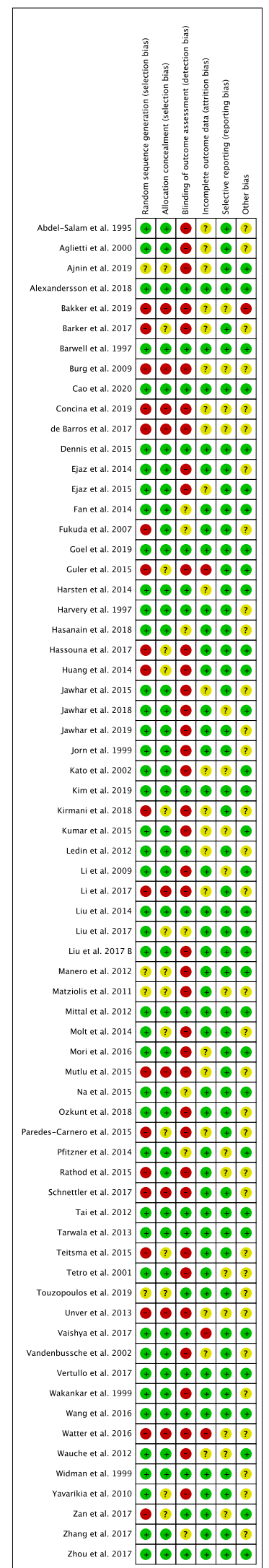

Open Access This article is licensed under a Creative Commons Attribution 4.0 International License, which permits use, sharing, adaptation, distribution and reproduction in any medium or format, as long as you give appropriate credit to the original author(s) and the source, provide a link to the Creative Commons licence, and indicate if changes were made. The images or other third party material in this article are included in the article's Creative Commons licence, unless indicated otherwise in a credit line to the material. If material is not included in the article's Creative Commons licence and your intended use is not permitted by statutory regulation or exceeds the permitted use, you will need to obtain permission directly from the copyright holder. To view a copy of this licence, visit http://creativecommons.org/licenses/by/4.0/.

Publisher's Note Springer Nature remains neutral with regard to jurisdictional claims in published maps and institutional affiliations. 